\title{
Effect of the SQ4R Technique on the Reading Comprehension of Elementary School 4th Grade Elementary School Students ${ }^{1}$
}

\section{Murat Başar}

Assoc. Prof. Uşak University, Faculty of Education, Turkey, muratbasar64@ gmail.com

\section{Mehmet Gürbüz}

Teacher, Uşak, Turkey, m.gurbuz32@gmail.com

The aim of this study is to examine the effect of SQ4R (Survey, Question, Read, Reflect, Recite, Review) technique of the reading comprehension ability of elementary school $4^{\text {th }}$ grade students. The sampling was constituted by 57 students from two different branches of the Ataturk Elementary School in the center of Usak region during the $2^{\text {nd }}$ semester of the 2013-2014 academic year. Reading comprehension skill achievement questions prepared by the researcher and it was used as the data collection tool. These questions were implemented to both groups before the experiment. Independent sample t-test and Kruskal Wallis-test methods were used for data analysis. According to the results of the study, a significant difference was found in the reading comprehension skills in favor of the students who studied reading comprehension with the SQ4R technique.

Key Words: Turkish language education, SQ4R technique, reading comprehension, reading comprehension strategies

\section{INTRODUCTION}

In our age of information, the subject of producing the knowledge has become more important rather than the subject of conveying it. In order for the knowledge to be produced, an individual shall use their advanced cognitive skills since their early age. An individual may learn to use these skills during the reading and comprehension education provided within the mother tongue education. One of the most effective skill areas of the comprehension education is listening and the other is reading. Comprehension can be developed by complete and correct acquisition of basic language skills (Akkaya, 2011: 69; Balta \& Demirel, 2012: 471).

\footnotetext{
${ }^{1}$ This study was adapted from a namesake thesis conducted under the consultancy of Assoc.Prof.Doc. Murat Başar at the Uşak University Department of Social Sciencesy.

Citation: Başar, M. \& Gürbüz, M. (2017). Effect of the SQ4R Technique on the Reading Comprehension of Elementary School 4th Grade Elementary School Students. International Journal of Instruction, 10(2), 131-144. https://doi.org/10.12973/iji.2017.1029a
} 
Mother tongue education plays a great role in teaching the students basic language skills. Texts used in education become progressively complex as the academic stage advances. It goes from basic comprehension level to texts with more complex literary language. Since phrases from texts with literary meaning have different meanings, such texts contribute to the development of students in terms of thinking and affection (Balta \& Demirel, 2012: 471; Genc, 2007: 48).

In this regard, Turkish language class, which provides mother tongue education and acquisition of basic skills, is of great importance. Of the four basic skills, speaking and listening can be taught partially outside of school. However, teaching the reading and writing skills is the job of formal education and these skills are being taught during Turkish language classes within the elementary schooling organizations (Belet \& Yasar, 2007: 70).

A large portion of learning activities in schools is performed by means of reading. Therefore, it creates the basis for learning. Reading basically consists of three elements. The first is the text, the second is the detection of the text by sense organs, and the third is interpretation and comprehension of the read text. If these three elements are implemented completely, a real reading is performed (Temizkan, 2007: 19, Temizyurek, 2008: 143).

Reading and comprehension takes place not only during the education period but in every field of life. Nowadays, people able to read and comprehend quickly are in demand. The reading comprehension skill, which has a strong relation to the academic success, should be developed since the first years of education (Yilmaz, 2011: 10; Anilan, 2004: 91).

Turkish language class has an important place in the academic life of individuals. Teaching of the basic skills that will affect their academic performance during the future years is carried out within the scope of this class. One of the most important of these skills is the reading comprehension skill. It is impossible to talk about enjoyment of academic success and learning unless the reading comprehension skill is sufficiently developed.

Researchers have produced various strategies since the past to present days in order to develop this skill. These techniques vary in terms of being applied before reading, during reading, after reading and throughout the process of reading. The SQ4R technique used during this study is among the techniques implemented throughout the whole process of reading.

This study is thought to provide a contribution to the field due to the lack of sufficient studies related to the effect of reading comprehension strategies on reading comprehension skills and related to the SQ4R technique in Turkey. Another element that contributes to the originality of the study is the use of open ended questions rather than multiple choice tests.

\section{SQ4R: Survey, Question, Read, Reflect, Recite, Review (SQ4R)}

SQ4R is a strategy especially designed for the use in explanatory and descriptive texts (Epcacan, 2009: 2016). Initially, it occurred as the SQ3R strategy. It became SQ4R after 
the Reflect step was added by Applegate et al. (1994). The steps of this strategy are as follows:

\section{1- Survey}

During the Survey step, the student first examines the text heading, its author and date of publication. Then skims over the main heading, sub-headings, illustrations, bold and italic words. At last, the students read the first and last sentences of the paragraphs (ElKoumy, 2004: 36; Brown, 1991: 59; Brown, 1992: 8, Gozniczak, 2007: 48). By means of surveying, the student acquires the skill to predict the subject of the text, its difficulty and knowledge to be acquired from the text (Brown, 1991: 59).

\section{2- Question}

At this stage, the student prepares questions that can be answered by the text. The questions are prepared by using the sub-headings and questions "who, what, where, why and how" (Brown, 1991: 59; El-Koumy, 2004: 36; Gozniczak, 2007: 48). The questions can be prepared by a teacher as well. However, no matter how they are prepared, the questions should definitely be prepared and should ensure that students are focused on the meaning of the text (Brown, 1991: 59). This stage ensures that students use their available knowledge and acquire a goal for reading (Epcacan, 2009: 216).

\section{3-Read}

At this stage the student carefully reads the text. The student may give verbal or nonverbal answers to the questions asked or underline the portions containing an answer during the reading stage (Brown, 1992: 8; El-Koumy, 2004: 36; Gozniczak, 2007: 48; Epcacan, 2009: 216).

\section{4- Reflect}

Reflecting requires the students to think about and evaluate the information acquired from reading and to find a relation to the available knowledge (Carter, 2011: 13). At this stage, the student gives verbal or written answers to questions asked after the reading stage (Brown, 1992: 9; Epcacan, 2009: 261) and summarizes the text (Brown, 1991: $60)$. Attention should be given to not use the textbook when answering the questions (Epcacan, 2009: 261).

\section{5- Recite}

At this stage the student checks whether they understood what they read and goes over the text while stopping at the questions in order to refresh and correct their notional scheme relating to the subject (Brown 1991: 60; Gozniczak, 2007: 49). This stage forces the student to directly participate in the recital process (Carter, 2011: 13).

\section{6- Review}

After all the said steps, the student goes over the reading text once more in order to summarize the subject, answers the questions they did not understand or did not remember, had problems answering (Epcacan, 2009: 261). This stage forces the reader to take place in the repetition and recital process in order to learn (Carter, 2011: 13). 


\section{The Goal of the Study}

The goal of this study is to examine the effect of SQ4R strategy on the reading comprehension skills of elementary school fourth grade students. Answers to the following questions were sought in this regard.

1. Is there a meaningful difference between the pre-test points acquired before the application among students from the experimental and control groups?

2. Is there a meaningful difference between the reading comprehension skills of the experimental and control group students after the application?

3. Is there a meaningful difference between the permanence test points of students from experimental and control groups?

4. Is there a meaningful relation between the student's monthly volume of reading and the reading comprehension skills?

\section{METHOD}

\section{Research Model}

Pre-test, post-test model with control group from the experimental research design, one of the quantitative research designs was used during the study. This model consists of two groups - the control group and the experimental group. Each group is subjected to pre-experimental and post-experimental measurements. In such studies, the pre-test points of both groups should be as close to each other as possible. Conducting the pretests in this model assists in determining the level of similarity between the groups prior to the experiment and in organizing the post-test results accordingly. In this model, the pre-test and post-test results are used in order to decide on the effectiveness of the independent variable. For that purpose;

$>\quad$ Percentage increase in pre-test post-test points is determined for each group and the average values are compared, or

$>$ Pre-test points are used as combined variable with the post-test points and the variability is analyzed, or,

$>\quad$ First the pre-test points are compared, if there is no significant difference, only the differences between averages are compared using the post-test points, or,

All or some of these can be tested (Karasar, 2011).

Students were administered a permanence test after 4 weeks following the post-test application. The cronbach alpha reliability coefficient was calculated and found to be .74 .

\section{Participants}

The participants of the study consists of a total of 57 students $(26$ students from the experimental group and 31 students from the control group) receiving education at the 
Ataturk Elementary School of the Usak regional center during the second semester of the 2013-2014 academic year. 27 of the students are male and 30 are female.

\section{Data Collection}

\section{Instruments}

Reading comprehension success questions written about the texts read by students and they were asked for the purpose of examining the study problems. They were open ended questions prepared under the review of specialized and class teacher in accordance with the Bloom's renewed taxonomy. Point weight of the questions is provided in the table below. Since the "create" step required a more advanced thinking skill during the interviews, it was decided to have a value of 5 points.

Table 1

Weight Table of the Reading Comprehension Success Questions Applied to the Students

\begin{tabular}{ll}
\hline Question Level & Question Point Weight \\
\hline Questions at the level of "Recall" & 1 point \\
\hline Questions at the level of "Understand" & 2 points \\
\hline Questions at the level of "Apply" & 3 points \\
\hline Questions at the level of "Analyze" & 3 points \\
\hline Questions at the level of "Evaluate" & 3 points \\
\hline Questions at the level of "Create" & 5 points \\
\hline
\end{tabular}

\section{Studies Performed with the Experimental and Control Groups}

1. A pre-experimental study was conducted at the Bugdayli Elementary School of the Usak region Karahanli district during the first semester of 2013-2014 academic year.

2. After the pre-experimental study, two classes with similar level of academic success in Turkish language lessons and teachers voluntarily participating in the study and comprising the experimental and control groups of the study from Ataturk Elementary School of Usak central region during the second semester of 2013-2014 academic year.

3. After determining the study group, introduction activities were performed with students from the experimental group for the first two weeks. Student information was verified by interviewing the teachers.

4. A test containing reading comprehension questions was implemented in order to examine the readiness of students in control and experimental groups.

5. After the pre-test, the experimental group received Turkish language classes by the researcher using the SQ4R technique for ten weeks, one hour per week. During the first two weeks, the researcher attempted to explain the SQ4R technique to the students as a model. As weeks went one, students implemented the technique independently.

6. No interventions were made to the Turkish language classes of the control group. Classes of the control group were conducted by the classroom teacher based on the teachers' guide book, students' textbooks and workbooks as was conducted previously.

7. Experimental and control groups were subjected to the post-test. 
8. A permanence test was applied to the experimental and control groups 4 weeks after the post-test.

Personal information of students was collected using a survey form prior to the pre-test used in order to measure the readiness level of students. Information as students' amount of pages read on monthly bases were collected and verified by interviewing the primary school teacher.

\section{Data Analysis}

Points earned by the students from pre-test, post-test and permanence test were entered by the researcher into the SPSS 19.00 software and analysis was carried as per the subproblem order. The descriptive analysis technique was implemented in order to determine the personal information of students. The independent $t$-test technique was implemented for the first, second and third sub-problems. Kruskal Wallis- test implemented fourth sub-problem.

\section{FINDINGS}

\section{Findings Related to the First Sub-Problem}

Results of the t-test conducted in order to determine the presence of any meaningful difference between the pre-test scores of experimental and control groups are presented in Table 2.

Table 2

$\mathrm{t}$-Test results of experimental and control group students according to Pre-Test scores

\begin{tabular}{lllllll}
\hline Groups & $N$ & Mean & SS & $s d$ & $T$ & $P$ \\
\hline Experimental Group & 26 & 2.96 & 1.08 & 55 & .10 & .927 \\
\hline Control Group & 31 & 2.94 & 1.06 & & & \\
\hline
\end{tabular}

When examining the Table 2, it can be seen that the reading comprehension skills of experimental group $(\mathrm{Avg}=2.96)$ is higher than the reading comprehension skills of the control group (Avg=2.94) which does not constitute a meaningful difference $[t(55)=.92$, p>.05]. Pre-test scores of the groups do not differ from each other. No difference can be observed between the groups in terms of readiness.

\section{Findings Related to the Second Sub-Problem}

Results of the t-test conducted in order to determine the presence of any meaningful difference between the post-test scores of experimental and control groups are presented in Table 3.

Table 3

t-Test results of experimental and control group students according to Post-Test scores

\begin{tabular}{lllllll}
\hline Groups & $N$ & Mean & $S S$ & $s d$ & $T$ & $p$ \\
\hline Experimental Group & 26 & 4.08 & .94 & 55 & 2.531 & $.000^{*}$ \\
\hline Control Group & 31 & 2.94 & 1.24 & & & \\
\hline
\end{tabular}


According to Table 3, the reading comprehension skills of experimental group students $(\mathrm{Avg}=4.08)$ is higher than that of the control group students $(\mathrm{Avg}=2.94)$. This difference between the two groups is found to be significant $[t(55)=2.531, \mathrm{p}<.001]$. According to the obtained findings, SQ4R was found to develop the reading comprehension skills of students. Students studying using the SQ4R technique better develop their reading comprehension skills.

\section{Findings Related to the Third Sub-Problem}

Results of the t-test conducted in order to determine the presence of a significant difference between the post-test scores and permanence test scores of experimental and control groups students are presented in Table 4.

Table 4

t-Test results of experimental and control group students according to Permanence Test scores

\begin{tabular}{lllllll}
\hline Groups & $N$ & Mean & SS & $s d$ & $T$ & $p$ \\
\hline Experimental Group & 26 & 4.12 & .65 & 55 & 1.064 & $.000^{*}$ \\
\cline { 1 - 4 } Control Group & 31 & 2.92 & .91 & & & \\
\hline
\end{tabular}

According to Table 4, the score average of experimental group ( $\mathrm{Avg}=4.12)$ is higher than that of the control group $(\mathrm{Avg}=2.92)$ and is found to be quite significant $[t(55)=1.064, \mathrm{p}<.001]$. This result determines that the SQ4R technique ensures permanence in reading comprehension. Score averages of students studying by the SQ4R technique partially increased according to the post-test, while they were found to have declined in the control group.

\section{Findings Related to the Fourth Sub-Problem}

The results of Kruskal Wallis test performed in order to determine presence of a significant difference between the monthly amount of pages read by students and their post-test scores are presented in Table 5.

Table 5

Kruskal Wallis Test Results of Students' Post-Test Scores in terms of Monthly Amount of Pages Read

\begin{tabular}{|c|c|c|c|c|c|}
\hline Number of Read Page & $N$ & Average Order & $X^{2}$ & $d f$ & $p$ \\
\hline 50 pages and less & 5 & 10.90 & 14.711 & 4 & $.005^{*}$ \\
\hline 51-100 pages & 3 & 10.67 & & & \\
\hline $101-150$ pages & 5 & 19.25 & & & \\
\hline 151-200 pages & 4 & 29.40 & & & \\
\hline 201 pages and more & 40 & 33.06 & & & \\
\hline Total & 57 & & & & \\
\hline
\end{tabular}

According to Table 5, a significant difference was found between the monthly amount of pages read by students and their post-test scores $\left[\mathrm{X}_{(4)}^{2}=14.711 ; \mathrm{p}<.05\right]$. The group of 
students with the highest average position scores is the group with monthly amount of pages read being 201 and more (33.06).

\section{DISCUSSION}

It is seen that pre-test scores of students from the experimental and the control groups have no significant difference. Pre-test score average of students from the experimental group was found to be 2.96 and that of the students from control group was found to be 2.94. It shows that the available knowledge and readiness of students from both groups are quite similar to each other. A total of 38 students from experimental and control groups of the research entitled "Effect of the Reading Comprehension and Problem Solving Strategies Applied During the Turkish Language Classes of 4th Grade Elementary School on Students' Success" and carried out by Bayrakci (2004) were subjected to a reading comprehension pre-test. According to the results, no significant difference was observed between the groups. A pre-test measuring the reading comprehension levels in terms of narrative texts was applied to a total of 60 students from experimental and control groups of the study entitled "Effect of Reading from Screen on the Reading Comprehension and Reading Motivation Levels of 5th Grade Elementary School Students" and carried out by Ileri (2011). As a result, no significant difference was observed between the groups. Ari (2014) did not find any difference among the groups according to the pre-test results for the study performed with the use of SQ3R (Survey, Question, Read, Recite, Review) technique.

A significant difference in favor of the experimental group was found between the scores in post-test applied to the experimental and control groups. The post-test score average of the experimental group was found to be 4.08 and that of the control group 2.94. These results show that the SQ4R technique significantly improves the reading comprehension skills of students. According to research carried out by Aycin (2009) titled "Impact of the ISOTEG Technique on the Reading Comprehension Success and Attitudes Towards Reading Among Fifth Grade Students: YIBO Example" shows that the ISOTEG technique significantly improved the reading comprehension skill. It can be said that various techniques and activities implemented during the teaching-learning process make a contribution to the reading comprehension skill and academic success. 48 students were subjected to a performance test to measure the level of comprehension of informative texts by Temizkan (2007) during a research titled "Impact of Reading Strategies on Reading Comprehension in Elementary School Second Stage Turkish Language Classes". When the results were examined, a significant difference was found in favor of the experimental group, where reading strategies were implemented. According to the post-test results of the study implementing the SQ3R technique with the SQ3R (Survey, Question, Read, Recite, Review) strategy performed by Ari (2014), the group that studied using the SQ3R technique was found to have higher performance. A study entitled "Impact of the Main Idea Finding Strategy on the Education Finding Main Idea and Reading Comprehension" carried out by Pilten (2007) determined a significant difference between the reading comprehension achievement level scores of experimental and control groups consisting of 67 students total. Studies performed by Basar (2011) and by Basar \& Akan (2013) have results supporting these findings. 
According to the studies, a conclusion was made that these activities provide positive contributions to the teaching-learning process. A study performed by Hudson et al. (2009) determined that various activities during reading contribute to the comprehension. Yakupoglu (2012) concluded in his study that the SQ4R technique contributes to the upper cognitive development in Turkish students. All these results show that reading comprehension strategies have a positive and significant impact on the reading comprehension skill.

It was found that the monthly amount of pages read by students develops their reading comprehension skills. It can be observed that post-test score average of students reading 201 and more pages is significantly higher than that of students reading 50 pages and less. According to Cogmen's (2008) study, a significant difference can be observed between the reading comprehension strategies and the frequency of reading books. It was determined that students reading 6 to 20 books a year use more reading strategies than those reading 1-5 books a year. Cogmen's research supports these findings. Cogmen also concluded that the reading comprehension skill level rose as the amount of pages read increased. Another finding of Sert's (2010) study is that reading comprehension scores of students with regular reading habits were higher than those of students with no regular reading habits. According to the study by Basar, Batur \& Karasu (2014), students' reading comprehension skill rises as the amount of pages read increases.

The results of Gunawan's (2016) study shows that SQ4R technique can increase the success of reading comprehensiveness \%66.29 more than other techniques. Rodli's study (2015) illustrates that SQ4R technique help students better understand what they are reading, as well as increasing the student's willingness to reading more. According to results of Wulandari and his colleagues' study (2016) SQ4R technique provides better mathematic learning achievement than SQ3R. Girls and boys taught with SQ4R had showed higher mathematic learning achievement than SQ3R.

\section{CONCLUSION}

Following conclusions were made from this study titled "Effect of the SQ4R Technique on the Reading Comprehension of Elementary School Fourth Grade Students".

1. No significant difference was found between the pre-test scores of students from experimental and control groups.

2. It was found that students implementing the SQ4R technique were more successful in reading comprehension. It is concluded that the SQ4R technique contributes to the reading comprehension skill of students.

3. It was observed that the SQ4R technique has a permanent effect on the reading comprehension skill.

4. The comprehension skill improves as the amount of pages read increases. 


\section{SUGGESTIONS}

\section{Suggestions for the results of the research}

The SQ4R technique improves students' reading comprehension skills. Teachers may use this technique in Turkish language and other classes.

Students' reading comprehension skill improves as the amount of pages read increases. Students should be encouraged to read.

SQ4R technique was ignored in the teacher's guidebook prepared by the Ministery of National Education. In other words, teachers may not aware of this technique. This technique can be added to teacher's guidebook to enable teacher to use the SQ4R technique.

\section{Suggestions for researchers}

This research studies the effect of SQ4R technique on the reading comprehension. The effect of SQ4R technique in various areas of different classes could be studied.

This study was conducted at the elementary school $4^{\text {th }}$ grade level. Results can be compared by implementing the study to different education levels. Additionally different variables could be searched.

The effect of the SQ4R technique on the reading comprehension can be compared with different reading comprehensive techniques.

\section{REFERENCES}

Akan, D. \& Başar, M. (2013). The effect of classroom activities on classroom management in the teaching-learning process: The case of Uşak City. Mevlana International Journal of Education 3(4), 147-165. http://dx.doi.org/10.13054/mije.13.63.3.4.

Akkaya, N. (2011). İlköğretim 8. Sınıf Türkçe dersinde okuduğunu anlama stratejilerini kullanmanın, tutuma etkileri. Milli Ĕgitim Dergisi, 191, 68-77.

Anılan, H. (2004). Bazı değişkenler açısından Türkçe dersinde okuduğunu anlama. $A K \ddot{U}$ Sosyal Bilimler Dergisi 6(2), 89-102.

Applegate, M., Quin, K., \& Applegate, A.J. (1994). Using metacognitive strategies to enhance achievement for at-risk liberal arts college students, Journal of Reading 38 (1), $32-42$.

Arı, G. (2014). The effect of SQ3R and dr-ta reading strategies used by fifth grade students on comprehension. Journal of Theory and Practice in Education 10(2), 535555 .

Ayçin, A.A. (2009). İSOTEG tekniğinin beşinci sınıf öğrencilerinin okuduğunu anlama başarısı ve okumaya yönelik tutumları üzerine etkisi: Yibo örneği (Unpublished doctoral dissertation), Çukurova University, Adana. 
Balta, E.E. \& Demirel, Ş. (2012). Waldmann modelinin 8. Sınıf öğrencilerinin okuduğunu anlama ve eleştirel düşünme becerilerine etkisi. Turkish Studies 7(3), 469479.

Başar, M. (2011). Sınıf içi istenmeyen öğrenci davranışlarının yönetiminde örtük program (Uşak ili örneği) (Unpublished doctoral dissertation), Marmara University, İstanbul.

Başar, M., Batur, Z., \& Karasu, M. (2014). Süreye bağlı sesli okumanın okuduğunu anlamaya etkisi. Milli Ĕgitim Dergisi 43(203), 5-21.

Bayrakçı, R. (2004). İlköğretim 4. sınıf Türkçe dersinde uygulanan okuduğunu anlama ve problem çözme stratejilerinin öğrenci başarılarına etkisi (Unpublished master's thesis), Selçuk University, Konya.

Belet, Ş.D. \& Yaşar, Ş. (2007). Öğrenme stratejilerinin okuduğunu anlama ve yazma becerileri ile Türkçe dersine ait tutumlara etkisi. Eğitimde Kuram ve Uygulama, 3(1), 69-86.

Brown, R.L. (1991). The effects of teaching a multicomponent reading strategy on university ESL students' reading comprehension and reports of reading strategies (Unpublished doctorate thesis), Michigan State University.

Brown, R.L. (1992). Developing reading competence in university ESL classes Annual International Conference of the Institute of Language in Education.

Çöğmen, S. (2008). Eğitim fakültesi öğrencilerinin kullandıkları okuduğunu anlama stratejileri (Unpublished master's thesis), Adnan Menderes University, Aydın.

El-Koumy, A.S.A.K. (2004). Metacognition and reading comprehension: Current trends in theory and research. Cairo: Anglo Egyptian Bookshop.

Epçaçan, C. (2009). Okuduğunu anlama stratejilerine genel bir bakış. Uluslararası Sosyal Araştırmalar Dergisi 2(6), 207-223.

Evans Carter, C. (2011). Mindscapes critical reading skills and strategies (Second Edt) Cangage Learning.

Genç, H. N. (2007). Betik türleri ve okuma. Dicle Üniversitesi Ziya Gökalp Eğitim Fakültesi Dergisi, 8, 45-51.

Gunawan, A. (2016). Penerapan strategi sq4r untuk meningkatkan aktivitas dan hasil belajar larutan penyangga bagi peserta didik kelas xi ipa-1 sma negeri 1 cepiring semester 2 tahun pelajaran 2015/2016. Majalah Ilmiah Inspiratif 2(2).

Guzniczak, L. A. (2007). A quasi-experimental study of adolescent learning using the sq3r strategy instruction with web-based learning materials (Unpublished doctoral dissertation), Oakland University.

Hudson, R, F. Pullen, P, C. Lane, H, B.\& Torgesen, J, K. (2009). The complex nature of reading fluency: A multidimensional view. Reading \&Writing Quarterly, 25(1), 4-32. 
İleri, Z. (2011). Ekrandan okumanın ilköğretim 5. sınıf öğrencilerinin okuduğunu anlama ve okuma motivasyonu düzeylerine etkisi. (Unpublished master's thesis), Sakarya University, Sakarya.

Karasar, N. (2011). Sosyal bilimlerde araştırma yöntemleri, Ankara: Nobel.

Pilten, G. (2007). Ana fikir bulma stratejisi öğretiminin ana fikir bulma ve okuduğunu anlamaya etkisi (Unpublished doctoral dissertation), Gazi University, Ankara.

Rodli, M. (2015). Applying PQ4R strategy for teaching reading. Indonesian EFL Journal 1(1), 31-41.

Sert, A. (2010). İlköğretim altıncı sınıf öğrencilerinin okuduğunu anlama becerilerinin bazı değişkenler açısından incelenmesi (Unpublished master's thesis), SelçukUniversity, Konya.

Temizkan, M. (2007). İlköğretim ikinci kademe Türkçe derslerinde okuma stratejilerinin okuduğunu anlama üzerindeki etkisi (Unpublished doctoral dissertation), GaziUniversity, Ankara.

Temizyürek, F. (2008). The impact of different types of texts on Turkish language reading comprehension at primary school grade eight students. Eurasian Journal of Educational Research 30, 141-152.

Yakupoğlu, F. (2012). The effects of cognitive and metacognitive strategy training on the reading performance of Turkish students. Practice and Theory in Systems of Education, 7(3), 353-358.

Yılmaz, M. (2011). İlköğretim 4. Sınıf öğrencilerinin okuduğunu anlama seviyeleri ile Türkçe, matematik, sosyal bilgiler ve fen ve teknoloji derslerindeki başarıları arasındaki ilişkinin belirlenmesi. Dumlupınar University Journal of Social Sciences, 29, 9-14.

Wulandari, S., Budiyono, Iswahyudi, G. (2016). Eksperimentasi model pembelajaran survey, question, read, recite, review (SQ3R) dan survey, question, read, reflect, recite, review (SQ4R) ditinjau dari jenis kelamin dan gaya belajar. Jurnal Elektronik Pembelajaran Matematika 4(1), 34-47. 


\section{Turkish Abstract}

\section{SQ4R Tekniğinin İlkokul 4. Sınıf Öğrencilerinin Okuduğunu Anlamaya Etkisi}

Bu çalışmanın amacı SQ44R (araştırma, soru sorma, okuma, ifade, anlatım, inceleme) tekniğinin İlkokul 4. sınıf öğrencilerinin okuduğunu anlama becerilerine olan etkisini araştırmaktır. Örnekleme, 2013-2014 akademik yılının ikinci döneminde Uşak merkezindeki Atatürk İlkokulu'ndaki iki farklı sınıfta toplam 57 öğrenciden oluşmaktadır. Okuduğunu anlama beceri soruları araştırmacı tarafından hazırlanmış ve veri toplama aracı olarak kullanılmıştır. Sorular her iki gruba da deneyden önce uygulanmıştır. Verilerin analizi için bağımsız t-testi ve Kruskal Wallis test yöntemleri kullanılmıştır. Çalışma sonuçlarına göre SQ4R tekniği kullanılan öğrencilerin okuduğunu anlama becerilerinde anlamlı bir farklılık bulunmuştur.

Anahtar Kelimeler: Türk dil eğitimi, SQ4R tekniği, okuduğunu anlama, okuduğunu anlama stratejileri

\section{French Abstract}

Effet de la Technique SQ4R sur la Compréhension Lisant de CM1 d'École primaire Étudiants Scolaires Elemantary

Le but de cette étude est d'examiner l'effet de SQ4R (l'Enquête(la Vue générale), la Question, Lue, Refléter, Réciter, l'Examen(la Revue)) la technique de la capacité de compréhension lisante d'étudiants de CM1 d'école primaire. L'échantillonnage a été constitué par 57 étudiants de deux branches différentes de l'École primaire Ataturk dans le centre de région Usak pendant le 2ème semestre du 2013-2014 an universitaire. Lisant des questions d'accomplissement d'habileté(de compétence) de compréhension préparées par le chercheur et il a été utilisé comme l'outil de collecte de données. Ces questions ont été mises en œuvre aux deux groupes avant l'expérience. Le t-test type indépendant et des méthodes de Wallis-test de Kruskal ont été utilisés pour l'analyse de données. Selon les résultats de l'étude, une différence significative a été trouvée dans les compétences de compréhension lisantes en faveur des étudiants qui ont étudié la compréhension lisante avec la technique SQ4R.

Mots Clés: éducation de langue turque, technique SQ4R, lisant compréhension, lisant stratégies de compréhension

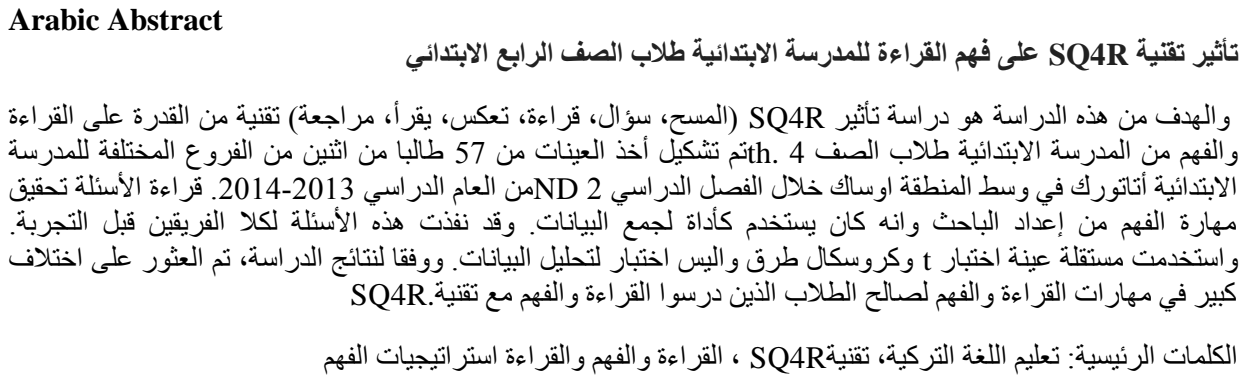




\section{German Abstract \\ Wirkung der SQ4R-Technik auf das Leseverständnis der Grundschule 4. Klasse Grundschüler}

Das Ziel dieser Studie ist es, die Wirkung von SQ4R (Umfrage, Frage, lesen, reflektieren, rezitieren, Überprüfung) Technik der Lese-Verständnis Fähigkeit der Grundschule 4. Klasse Studenten zu untersuchen. Die Probenahme bestand aus 57 verschiedenen Zweigen der AtatürkGrundschule im Zentrum der Region Usak im 2. Semester des Studienjahres 2013-2014. Lesen von Verständnis Fähigkeiten Leistung Fragen von den Forschern vorbereitet und es wurde als Datenerfassung Werkzeug verwendet. Diese Fragen wurden für beide Gruppen vor dem Experiment durchgeführt. Für die Datenanalyse wurden unabhängige Stichproben-t-Tests und Kruskal Wallis-Testmethoden verwendet. Nach den Ergebnissen der Studie wurde ein signifikanter Unterschied in den Leseverstehen zugunsten der Studierenden gefunden, die das Leseverstehen mit der SQ4R-Technik studierten.

Schlüsselwörter: Türkisch sprachunterricht, SQ4R technik, leseverstehen, leseverstehen strategien

\section{Malaysian Abstract \\ Kesan Teknik SQ4R pada Kefahaman Membaca Pelajar Sekolah Rendah Tahun Empat}

Tujuan kajian ini adalah untuk mengkaji kesan SQ4R (Survey, Question, Read, Reflect, Recite, Review) teknik keupayaan membaca kefahaman pelajar kelas 4 sekolah rendah. Pensampelan terdiri daripada 57 pelajar dari dua cabang yang berbeza dari Ataturk Elementary School di tengah-tengah kawasan Usak pada semester ke-2 2013-2014 tahun akademik. Membaca soalan yang menguji pencapaian kemahiran disediakan oleh pengkaji dan ia telah digunakan sebagai alat pengumpulan data. Soalan-soalan ini telah dilaksanakan untuk kedua-dua kumpulan sebelum percubaan. Kaedah ujian-t bebas dan Kruskal Wallis telah digunakan untuk analisis data. Menurut hasil kajian itu, perbezaan yang signifikan dalam kemahiran membaca kefahaman memihak kepada pelajar yang belajar kefahaman membaca dengan teknik SQ4R.

Kata Kunci: pendidikan Turki bahasa, teknik SQ4R, kefahaman membaca, membaca strategi kefahaman

\section{Russian Abstract \\ Эффект Техники SQ4R на Чтение Постижения Начальной Школы 4-Го Класса Учащиеся Начальной Школы}

Целью данного исследования является изучение эффект SQ4R методики (Survey, Question, Read, Reflect, Recite, Review - Обследование, Вопрос, Читать, Отражать, Читайте, Обзор) на постижение читательской способности в начальной школе учащихся 4-го класса. Выборка была составлена 57 студентами из двух разных отделений начальной школы Ататюрка, в центре Усакской области, во втором семестре 2013-2014 учебного года. Чтения, Вопросы, подготовленные исследователем, использовался в качестве данных сбора материала. Эти вопросы были применены к обеим группам перед экспериментом. Для анализа данных были использованы независимый t-тест и Kruskal Wallis-методы испытаний. По результатам исследования было обнаружено значительное различие в чтение постижения навыки, в пользу студентов, которые изучали понимание прочитанного с помощью техники SQ4R.

Ключевые Слова: образование на Турецком Языке, техника SQ4R, понимание прочитанного, стратегии понимания прочитанного 